Article

\title{
Environmental Protection Regulations in the Light of Public Law and Social Obligations
}

\author{
Nima Norouzi ${ }^{1,}{ }^{*}$, Elham Ataei ${ }^{2}$ \\ ${ }^{1}$ School of Law, Department of Human Sciences, Islamic Azad University, Tehran, Iran \\ ${ }^{2}$ School of Political Science and International Relationships, Payam Noor University, Tehran, Iran \\ *Correspondence: n.nima1376@gmail.com
}

How to cite this paper: Norouzi, N., \& Ataei, E. (2021). Environmental Protection Regulations in the Light of Public Law and Social Obligations. Research Journal of Ecology and Environmental Sciences, 1(1), 1-16. Retrieved from https://www.scipublications.com/journal/index.php/rjees/article/view/52

\begin{abstract}
Environmental regulation is one of the most important subsets of social regulation. Regulation is a framework for implementing the rules adopted in society, and legal standards guarantee this framework. Thus, if the legislation prohibits the dumping of waste on public waterways and imposes a penalty for its violation, this prohibition can be interpreted as an expression of society's public commitment to environmental protection and public condemnation of polluting behaviors. On the other hand, it can be said that the destruction of the environment is morally wrong, and therefore the legal prohibition of these behaviors can be interpreted as an expression of this moral claim. This research is based on library studies and descriptive-analytical methods and has an innovative approach. The purpose of this study is to explain the role of law as a facilitator of the executive structure of environmental regulation inappropriate conditions in line with social interaction. It also seeks to explain the importance of regulation and regulation. Regulation is one of the most important social standards and guarantees the strong implementation of legal obligations in society. This fundamental standard has been established in public law and seems to be an important approach to protecting the environment and citizens' adherence to environmental obligations.
\end{abstract}

Keywords: Regulation; Public Rights; Environmental Law; Public Diplomacy; Citizenship Obligations

\section{Introduction}

One of the basic tasks of governments is to regulate public affairs through regulation. Regulation is a tool or process that can largely reflect the mechanisms of government involvement and intervention in social affairs. However, the progress and achievements of regulation in recent years have led to the extension of regulation logic from economics to other areas such as the environment, labor and employer relations, consumer protection, etc.

Regulation regulates all social spheres and mechanisms of social control, whether conscious, intentional, or unintentional [1]. Regulation can include any attempt by the government to influence human behavior [2]. It is often claimed that we live in an age of "regulatory government." In other words, regulation is the developed part of the modern government.

Social regulation forces individuals and companies, or lower levels of government, Copyright: (c) 2021 by the authors. Submitted for possible open access publication under the terms and conditions of the Creative Commons Attribution (CC BY) license (http://creativecommons.org/licenses /by/4.0/). to take certain measures to improve public welfare. In a law-abiding society with a free system, social frameworks are established by considering citizenship situations. This means that the decisions of the general public can implement economic, social, cultural, health, political and environmental tools, and government interventions are less visible and, if they exist, are more to facilitate matters. In this regard, one of the most important social levels is environmental protection and public health, and having a healthy environment. In this way, to achieve the goals in the framework of law-abiding citizen relations, 
the originality of this is important in the light of customary rules and norms. However, environmental regulation indicates the need for civil society to adopt a social regulation approach. Although regulation takes place at various levels upstream, including the executive and the legislature, and sometimes beyond the decision-making powers, and sometimes intermediate, including the ministry or the directorate, in this process, environmental regulators, especially at the legislative level, play a role. They play a very important role.

On the one hand, it seems that environmental regulation itself is a comprehensive framework and is at the top due to its great importance. On the other hand, we may look down on the environment and see this as a subset of social regulation. In any case, government interventions are justified despite social weaknesses. Despite all these issues, environmental regulation is important, politically, economically, culturally, and socially. In this regard, the aspect of environmental regulation legally leads us to examine the environmental effects. This research tries to deal with one of the important tools for resolving social and health, and environmental disasters from a legal perspective under environmental regulation.

\section{Principles of Lawmaking}

About the regulation principles, the community needs legal frameworks for the action and implementation of legislative norms by citizens [4]. Therefore, regulation can be done in all social matters, including environmental issues, and communities have the right to ask the government to achieve some degree of social justice. The most important theory in the field of regulation is the theory of public interest. Accordingly, the government regulates places where economic activity has external and environmental effects or an asymmetry of information in which the government enters [5]. Therefore, in this regard, regulatory institutions are considered experts who correct the existing shortcomings and actions in the public interest [6].

\subsection{Regulatory Objectives}

Social regulation examines the effects of economic activities on the social welfare of citizens [7]. Due to the increasing complexity of public affairs in today's world, legislators must be aware of the objectives they have set for their enactment and be fully aware of the various effects that an enactment has on the economic, social, social, cultural, and environmental sectors. In addition, experience shows that creating harmony and balance between different policies and regulations can be more effective in integrating the overall regulatory system of the country.

\subsection{Principles of regulation}

With the formation of the regulatory government as the governing paradigm in public sector management, increasing attention has been paid to the preparation and implementation of good regulation, which is one of the important tools. Achieving the goals of the regulatory system is considered [8]. The description of goodness and desirability of regulations can be focused on the aspect of quantity, quality, or both [9]. Quantity oversees the number of regulations, bylaws, and sections of applicable regulations. Numerous laws and regulations are considered a factor that impedes access to the law and its transparency and sometimes efficiency. The quantity of regulations harms its quality. Recently, this focus on the quality of regulations has been used in a broader sense, and the idea has been put forward that if one authority approves a regulation, in any case, another authority must improve its quality [10]. Therefore, optimal regulation regarding quantity and quality should consider the social growth cycle and social standards. In this regard, the excellence of social growth depends on ensuring the participation of development and 
achieving it towards sustainable development. Its realization depends on protecting human rights, including the right to a healthy environment and its protection(see Figure 1).

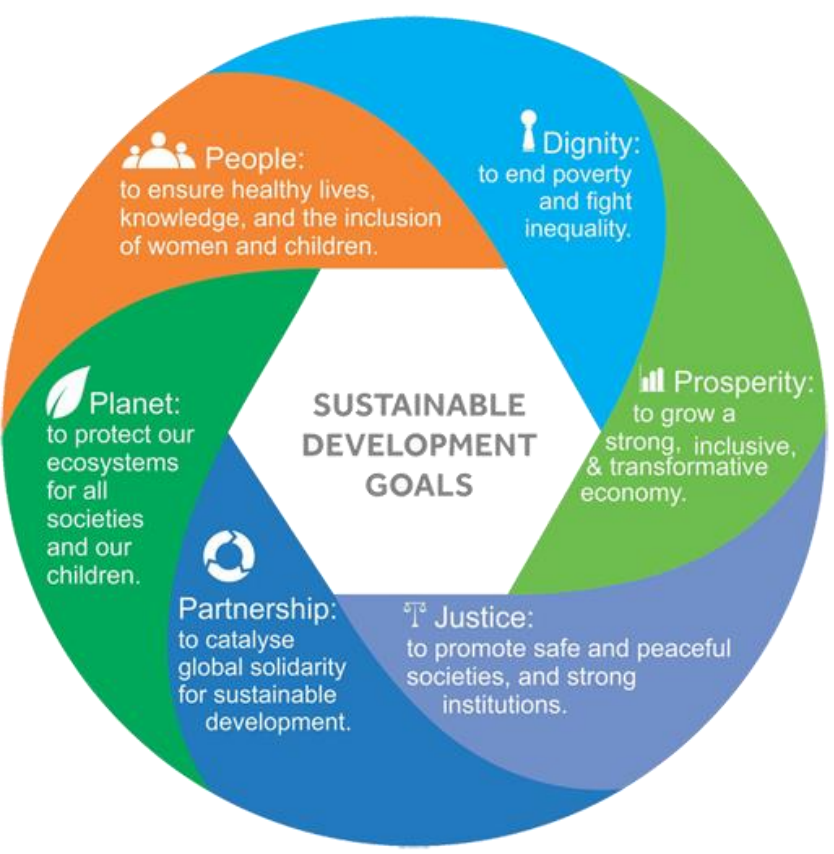

Figure 1. Social growth cycle and citizenship rights

\subsection{Transition Regulation Institutions}

The Environmental Protection Agency is considered a cross-sectoral organization at the national level as a regulatory body. Municipalities also regulate as a structure. In this regard, regulation is determining the manner of implementation of regulations and approvals. The general policies of the system are regulated when they are implemented. The Sixth Development Plan and the Charter of Civil Rights, which also consider environmental aspects, are, in fact, policies that take place after the adoption of existing regulations[11]

\subsection{Competence of transitional regulatory bodies}

Among the most important powers vested in regulatory bodies is the regulatory authority, licensing of regulatory companies, imposing fines or suspensions on infringing companies, enforcing rules, and in some cases resolving disputes. However, most of the literature on the competence of regulatory bodies is related to their regulatory competence [12]. Therefore, regulation is the most important competence of regulatory bodies.

\section{Environmental regulation}

Although the environment is the most important component of human life, its true value and assistance have not yet been properly identified, so that one of the most important challenges facing governments in the 21st century is environmental crises. That is why governments try to adopt various policies and programs are based on field surveys' results to overcome environmental problems or reduce the negative effects of human functions on the environment [13]. For example, in Iran, in recent years, in the form of regulations and five-year plans, efforts have been made to protect the environment and reduce environmental pollution.

Environmental protection involves social and economic regulation because the source of the problems associated with it is usually economic, and their negative effects 
are often social. In this regard, the government has the role of paving the way for realizing the desired structure(see Figure 2).

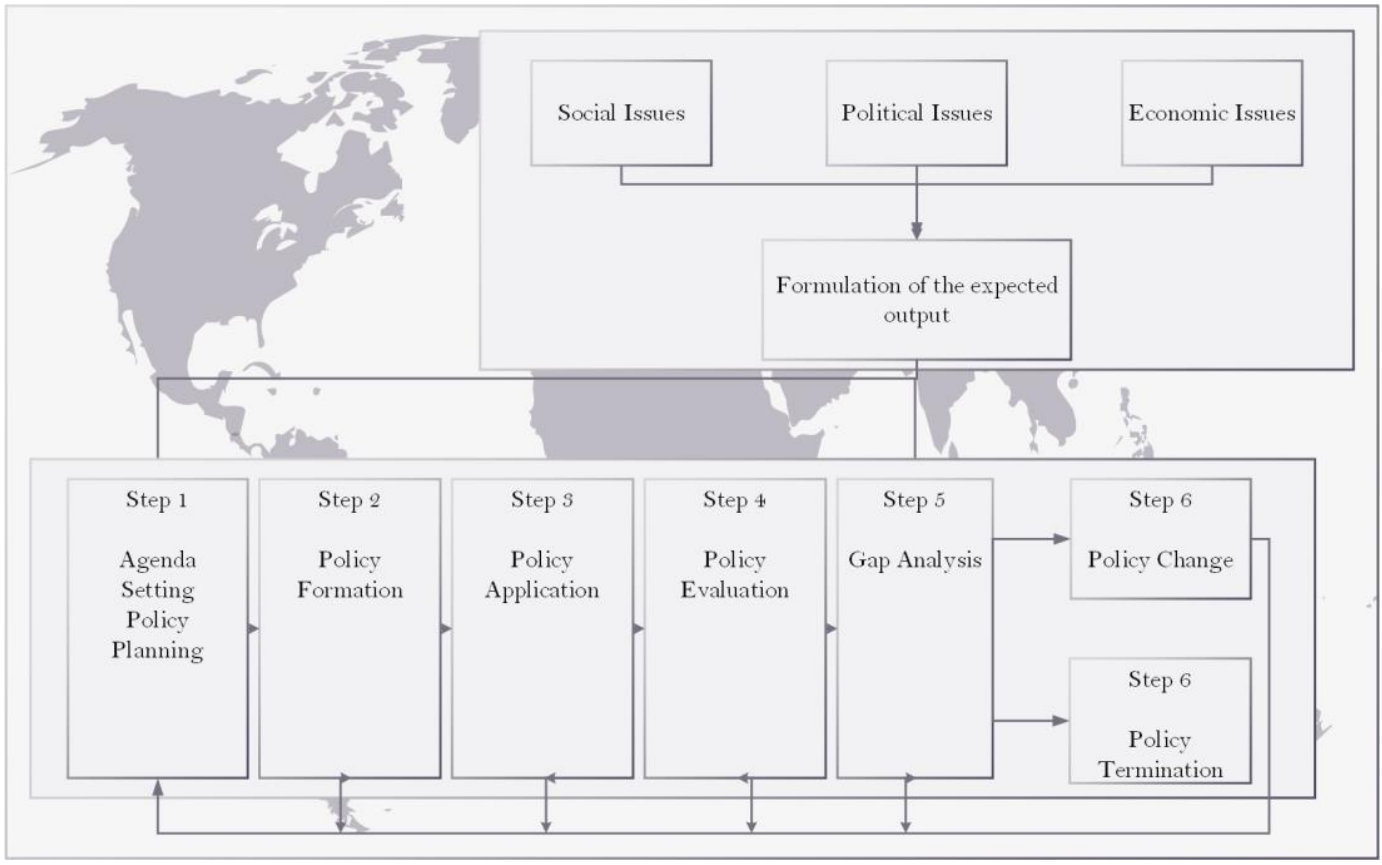

Figure 2. Policy-making framework

With this description, regulation based on social conditions should be comprehensive, and the government will make the most effective measures in this regard. This regulation in the field of the environment is undoubtedly undeniable [14]. Table 1 shows some common examples of environmental and health-related regulations.

Table 1. Examples of environmental regulations in the field of health

\begin{tabular}{|c|c|}
\hline Regulation & Examples \\
\hline $\begin{array}{c}\text { Social regulation (security, health welfare, } \\
\text { public health, and ethics) }\end{array}$ & $\begin{array}{c}\text { Apply safety standards in the construction and opera- } \\
\text { tion of buildings, roads, bridges, ports, airports, nuclear } \\
\text { weapons factories, cars, aircraft, machinery, etc. }\end{array}$ \\
\hline $\begin{array}{c}\text { Enforce rules on private exploitation of } \\
\text { mines, forests, wildlife, barren lands, and } \\
\text { other natural resources. }\end{array}$ & $\begin{array}{c}\text { Prohibition of air, water, and other environmental pro- } \\
\text { tection, forests, pastures, and plant and animal species. }\end{array}$ \\
\hline $\begin{array}{c}\text { Control the spread of infectious and epidemic } \\
\text { diseases through methods such as quarantine. }\end{array}$ & $\begin{array}{c}\text { Zoning regulations and prohibiting the posting of ad- } \\
\text { vertisements from preserving the beauty of the living } \\
\text { environment. }\end{array}$ \\
\hline
\end{tabular}

\subsection{Incomplete regulatory pathologies}

One of the shortcomings in today's society is the weak rule of law in the light of its relational practices. Lack of regulation in this direction has taken the citizens out of the circle of the rule of law and lawlessness. This anomaly has caused people to not react well to the rules and norms around them, and the founders of regulation have not done their job properly. In the opinion, it seems that the spirit of cooperation and interaction in decision-making structures has been greatly degraded and has not been significant. Due to administrative bureaucracies and a lack of discipline, regulation is difficult. However, 
sometimes this problem arises from structural anomalies and heterogeneities. This has led to crises such as environmental crises in society. Accordingly, regulatory failures are undesirable because of the heterogeneity between decisions and do not maintain a social normative balance. In this regard, this failure also causes excessive costs due to adverse activities and causes pollution and destruction of the environment.

\subsection{Legal standardization}

In the context of legal review, regulation is one aspect of legislation, which takes place at the supra-sectoral (parliamentary) and sectoral (environmental protection organization) and inter-sectoral (municipal) levels, and the other aspect is structural monitoring and evaluation and its consequences. Evaluating the effects of technical regulations to improve the quality of regulations is based on experience, which is done through systematic and continuous assessment of their potential effects, in other words, it is a policy tool that evaluates the effects in terms of costs, benefits, and risks of each proposed law [15]. This evaluation method has been pursued following the expansion of the tendency to improve and reform the regulatory system after the "inefficiencies" of government intervention in public affairs in some countries of the world. Therefore, it seems that the legal standard will be a reliable cornerstone for environmental regulation, and this framework should be maintained. However, environmental regulation is also the subject of various legal challenges from multiple legal sources. The main issue in this regard is the observance of the ritual and legal process of regulation. However, legal considerations influence the decision to use socio-environmental regulation as a tool of governance.

\section{Challenges of Environmental Law}

The development and codification of international law are among the main and fundamental tasks of the United Nations Commission on International Law [7], specified in paragraph 1 of Article 13 of the UN Charter with the same title. In addition, the United Nations Environment Program has played an important role in the development and drafting of international environmental law, and since its inception, it has proposed several binding and non-binding instruments to governments for ratification. In addition, governments and other international organizations, both governmental and non-governmental, have played important roles in developing and codifying international environmental law in recent years. Environmental protection, at least in its modern sense, which began in the 1970s and continues to this day, encompassed various areas such as air, soil, forest, and water and ratified various conventions in this area. The context reflects the importance of contemporary international law in this regard [1]. Undoubtedly, environmental protection is one of the concerns and concerns of today's human societies. Explosive population growth, unreasonable exploitation of natural resources, degradation and degradation of biodiversity, and increasing pollution have affected the air, soil, and water of the world in various ways, finally degrading the natural quality of human life. As a result, the disturbance of the balance and appropriateness of the environment has led governments, organizations, and international organizations to formulate and implement laws and regulations to prevent pollution and environmental degradation. The formulation of binding environmental principles and rules has gradually led to the development of environmental law, both nationally and internationally. In non-governmental organizations, global public opinion calls on their governments to take the necessary measures to protect the region and the environment. In practice, environmental laws can be considered mandatory criteria, criteria that It has been accepted as a valid criterion by the competent authority in the society. The obligatory nature of the law and the guarantee of implementation provide legal rules to prevent harmful behavior to the environment. Thus, 
efforts to regulate environmental protection were made in the 1970s, especially after environmentalists warned of its widespread destruction, especially by industrialized countries [2] because international environmental law for the global protection of the environment has been developed by the international community through the enactment and implementation of binding and non-binding legal rules and has developed in terms of content, form, and structure in recent decades. However, despite international efforts to protect the environment, environmental challenges persist and have increased significantly in many areas. Today's world's environmental concerns and threats go beyond experts' and scientists' predictions at the first Stockholm International Human and Environment Conference in 1972. Ozone depletion, climate change, air pollution, soil and water, biodiversity loss, deforestation, and desertification are the most important problems facing human beings today [2]. Thus, despite global efforts to enact and enforce international environmental law, failure to reduce environmental degradation and increase environmental pollution indicates the inefficiency and inefficiency of this legal field. Using a critical approach, this article seeks to address the obstacles and shortcomings of international environmental law while showing the existing capacities for development and proposing legal and executive gaps to address them. There are three important challenges to the substantive development of international environmental law:

\subsection{Reluctance of governments to delegate national sovereignty}

Regardless of the concept of sovereignty in public international law and international environmental law, one of the main obstacles to the development of international environmental law is the reluctance of governments to delegate or limit sovereignty to the benefit of international environmental organizations. The political structure of government always tends to focus and has no interest in delegating it to other centers of power and decision-making. On the other hand, the conflict of interests between the main actors of international law (states) regarding environmental protection, which arises from the national sovereignty of states, challenges the development and expansion of international law. This conflict of interests can include political, economic, commercial interests, etc. In addition, the conflict of interest of developing countries and developed countries in the application and enforcement of the rules and regulations of international environmental law is also one of the limitations of this legal field. Despite the principle of shared but distinct responsibility, in many sources of international environmental law, conflict is seen between these two groups of developed and developing states. The International Court of Justice's advisory ruling on the legitimacy of the threat and use of nuclear weapons in 1996 is a clear example of the pressure exerted on this international body by nuclearweapon states. However, one of the most important principles enshrined in the Stockholm Declaration of 1972 so far in international environmental declarations is the principle of sovereignty, which redefines the sovereignty of states and a new definition of the concept of sovereignty in international environmental law based on the concept of "use." Fair and reasonable "of the land, but the shadow of absolute sovereignty still weighs heavily on international environmental law [2]. But the fundamental problem is how governments participate in exercising this kind of sovereignty. Countries' differing positions on the world's environmental landscape, including the Nordic countries, which can influence and direct international budgets and accelerate various processes, are a source of concern, such as the United States' refusal to ratify a major agreement. In recent governments, as a result of tensions with Europe and Japan and the protests of southern countries, can have a significant impact on the process of international environmental governance. Thus, the refusal of a country like the United States from its international environmental obligations has catastrophic consequences in the validity and application of environmental governance policies and policies invented by other northern countries. The legitimacy of these 
countries among the southern countries to the recipient of environmental aid will be lost due to a lack of cooperation and coordination among donor countries and will lead to the risk of non-cooperation between institutions and the suspension of aid. This is evident in the Convention on Biological Diversity and the Kyoto Protocol, and the United Nations. The crises and challenges of international environmental governance Governance in pluralistic management should consider specific social and environmental policies and activities by integrating experience and knowledge in various institutions and effective social factors. And apply. Increasing environmental problems in terms of climate change, biodiversity loss and natural ecosystem degradation, increased pollution, precautionary principle, and transgenic organisms, the risk of nuclear radiation, freshwater scarcity on a very large scale as threats should be effective factors in exacerbating the crisis and Economic development prospects in different countries and regions are limited, controlled and managed [3]. The measures taken and ongoing to protect the environment against the scientific community's warnings are insufficient, and the necessary reforms to improve this protection process require time, energy, financial resources, and most importantly, diplomatic negotiations and consultations. The serious crisis of environmental degradation and the inability to deal with it unanimously have become a topic for all countries. But persistent differences and slow progress in organizing this crisis are serious challenges to governance [4].

\subsection{Multiplicity and diversity of sources of international environmental law}

Another substantive challenge to the development of international environmental law is the multiplicity and diversity of binding and non-binding resources. Soft or nonbinding rights are resources that are not binding and do not guarantee specific implementation, which include: statements, resolutions, agendas, action plans, and so on. Their main purpose is to express the principles and rules that guide governments. Although these resources are not binding in themselves, they have a very important impact on the development of international environmental law. The most important examples of these sources are the 1972 Stockholm Declaration on Man and the Environment, the World Charter of Nature adopted by the 1982 UN General Assembly, and the Rio Declarations of 1992, Johannesburg 2002, and finally, the Rio + 20 Declaration of 2012. They had a law. In addition, Agenda 21, adopted in 1992 on the sidelines of the Rio Summit, is a nonbinding legal instrument containing important guidelines for protecting, protecting, and managing the environment[2]. United Nations General Assembly resolutions and statements by the UNP Board of Governors; should also be considered a non-binding instrument in international environmental law. During this period, many international conventions were formed, including the Convention on International Trade in Endangered Species of Wild Fauna and Flora, the 1973 Washington Convention on the Law of the Sea, the 1982 Monte Gobi Convention, and many other conventions. They usually had an organization and structure for that convention. Today, most of the sources of international law are contained in the first paragraph of Article 38 of the Statute of the International Court of Justice.According to paragraph 1 of Article 38 of the Statute, the Court has to settle disputes according to international law and implement the following standards. International treaties, public (private) or private (private), [9] which establish rules (legal) and are explicitly recognized by the parties to the dispute; International custom as the reason for the general procedure that has been accepted as a legal rule; General principles of law recognized by civilized nations; According to the provisions of Article 59 of the Articles of Association [10], judicial decisions and the opinions of the most competent public law experts of different nations are considered as a subsidiary (auxiliary) knowledge of legal rules; Article 38 also stipulates that the provisions of this article do not impair the discretion of the Court in issuing a judgment following the (rule of fairness and discretion) [11], 
provided that the litigants agree to it [5]. However, today Article 38 of the Statute of the Court does not provide a complete picture of the sources of international law, but rather the international rules, unilateral legal actions of countries, and binding resolutions of international organizations, each of which is effective in regulating international legal relations and can serve as a source. International law to play a role. Despite their thematic diversity and geographical scope, international environmental treaties have common features, use similar legal techniques, and are often interrelated. Features such as the absence of retaliation in commitments, related materials or references from one document to another, structural protocol agreements, the creation of new institutions or the facilitation of existing or former institutions to promote continuous cooperation, the existence of rituals and innovative practices related to adherence and Non-compliance of the contracting members is the existence of a mechanism to correct and review their common funds. However, more than 300 multilateral treaties and 700 bilateral environmental agreements have led to the sequence and multiplicity of this source of rights, which is considered one of the essential challenges in the development of international environmental law. (6) Custom also plays an important role as another source of international environmental law, and many issues, such as the international responsibility of governments, especially in the field of transboundary pollution, have customary roots. The number of other international treaties and instruments that enshrine the same legal rules related to the environment in international treaties is increasing. The work of the UN Commission on International Law shows that the inclusion of customary rules in many international instruments can be considered a substantial development of international environmental law. General principles of international law, although not sufficient to protect the environment, but due to unsystematic development, treaty law remains in force. Principles of unity, resources, and responsibilities. The common heritage of humanity is also one of the basic rules in this branch of law. On the other hand, the issuance of judicial rulings plays an important role in developing this field of law. International environmental law, in its short life, has been able to study and study solutions in terms of the potential importance of the environment; Issues such as the international responsibility of polluters, the obligations of governments towards their ratified treaties, and finally, the criminal liability for environmental degradation are among the important issues of international environmental law. But in international environmental law, despite the large volume of binding and non-binding documents and adherence to international custom, to fulfill the international responsibility of governments is not without difficulty. As many legal opinions and procedures have shown, adherence is not customary in limited cases.

Thus, the custom seems to have lost its traditional effectiveness in international environmental law, and for customers to be effective in international law, it is necessary to consider the behaviors and practices of governments in environmental protection (2). Therefore, due to the novelty of this field of law, sources in international environmental law, and these sources, there are other sources such as international rules of procedure, international obligations of states [12] and UN resolutions, and UN Security Council resolutions and resolutions are cited. Are. This multiplicity of resources, especially in the large number of international treaties that sometimes have similar or sometimes conflicting obligations, has challenged the implementation of international environmental law.

\subsection{Insufficient guarantee for the implementation of international environmental law}

Another essential challenge of international environmental law is the inadequacy of the enforcement guarantee. To implement a legal system, after going through the rules, it must be thought that its implementation guarantees an important role. This issue in the world community; has different forms because governments are never willing to jeopardize their national interests against each other. Even in some cases, there are shortcomings 
in the domestic laws to support this issue. Due to the sovereignty of governments and their role, there is an obstacle to the effective allocation and enforceability of these documents (7).

On the other hand, the existing enforcement mechanisms will sometimes be forced to retreat in the face of pressure from governments. Unlike the domestic law system of countries, international law lacks coherent enforcement mechanisms such as the executive, the administrative police, or the judiciary. Existing classical safeguards, such as criminal or civil warranties, do not work, and many environmental issues, despite being crossborder and non-refundable.

\subsection{Structural challenges of international environmental law}

With the rise of global environmental protection since the 1970s, this mission has been directly or indirectly reflected in many international organizations' goals. In the meantime, international governmental organizations, both global and regional, and even non-governmental organizations have tried to play their role in environmental protection and commit their members to international environmental regulations to support Take a step away from the environment. Undoubtedly, as active subjects of international law, international organizations have a serious task to achieve in this regard. The number of these organizations that today have some kind of environmental competence is important (8). Almost every international governmental organization has somehow gotten into the subject of the environment. The world community is aware that environmental protection is very important for the well-being of the world community and ecosystems and sustainable development. For this reason, environmental protection and sustainable economic development are at the center of the agenda of international and regional international organizations. In addition to the United Nations, other international organizations also offer programs in this direction. In this regard, one of the important reflections of the UN Conference on Man and the Environment, Stockholm, 1972, was the establishment of the United Nations Environment Program [13] as the global and executive arm of the organization in the field of environment and its preservation in A subset of this organization was established. Accordingly, it was tasked with assessing the state of the global environment, formulating global environmental programs, and providing the necessary funding for these matters [9]. It is one of the United Nations-affiliated bodies, in other words, the only UN mechanism that has the authority to policy, coordinate and encourage various environmental issues between governments and specialized agencies of the United Nations and other organizations. It has international governmental and non-governmental organizations. The United Nations Environment Program was established to monitor the state of the global environment and the effects of national and international environmental policies and measures. The General Assembly in 1997, while emphasizing UNEP as the United Nations Chief Agent in the field of environment, called on it to be the main custodian of the global environment and to set the world environmental agenda and to promote and coherently implement the environmental dimensions of sustainable development[10]. The UNEP program is headquartered in Nairobi, the capital of Kenya, and from there is responsible for directing programs and managing the work of other offices that were later established in other countries. The United Nations Environment Program's headquarters in Africa will help understand the pattern of environmental issues facing developing countries [9]. The main goal of the United Nations Environment Program is to establish and encourage international coordination and cooperation to protect the environment. UNEP is also a center for informing the governments and people of the world and a means to improve their living standards without harming the rights of future generations. In other words, UNEP is an institution that advocates the prudent use of the environment and sustainable development. UNEP also works with the United Nations, international 
organizations, governments, non-governmental organizations, the private sector, and civil society to achieve its goals [11]. Accordingly, the United Nations Environment Program, as one of the most fundamental structures of global environmental protection, has a distinct position compared to other international organizations. However, according to their field of work in implementing environmental programs, other organizations act following their authority, all of which have been created with one purpose: to protect the environment. The current challenges facing the environmental system at the international level reveal the need to review the institutions' structure. Although all these efforts aim to address environmental sustainability concerns, they are still witnessing environmental degradation and the non-implementation of decisions and aspirations of related institutions. The lack of coordination in the environmental system is due to the structural weakness of international environmental law. However, the structural development of international environmental law has been challenged by international competition and conflict between governments, especially developed and developing countries. Although the United Nations Environment Program is a United Nations body that oversees and directs the environmental activities of its members, it continues to function as a program to become the "World Environment Organization," which has Universal and more complete powers that face limitations. The United Nations Environment Program, as the United Nations Main Program for Environmental Protection, despite its many successes in protecting the global environment, does not have the authority to enforce the rules and regulations of international environmental law on a global scale. Therefore, the need to revise this program to upgrade its current position or change its dependence on the United Nations is inevitable.

\section{Environmental justice and sustainable development}

The environment is the first human right. Without a secure environment, one cannot claim to have other political, social, or economic rights. The environment is defined as all external factors affecting the life and activity of living things, plants, and humans. So the environment refers to everything around us that can affect human and non-human life [1]. For example, X's environment has trees, water, sun, air, other people, etc. The idea of X's life and existence, assuming the support of others for the realization and flourishing of his humanity, means that he needs the government and the relationship in the social framework, he needs plants to provide food, clothing, and oxygen, he needs to travel to the sea and energy and to set the clock requires the sun. In principle, a man needs his environment and needs to be familiar with its functions [2].

As we have said, not only human life is affected by the environment, and it is not only human beings who are in the environment and not only human beings who live in the environment, but also the lives of other living beings and plants are affected by the activities around them. For example, plant and animal life are affected when humans cut down trees. Environmental studies have always proven the interdependence of living organisms and their interaction with the environment [3]. Therefore, the treatment of the environment needs a lot of attention. The normative questions that arise are whether human behavior with the environment is fair. Does non-human life (e.g., animals) have a right to the environment? Are the past and present lifestyles of global citizens fair to future citizens of the world? These are just some of the goal-setting sharewares that you can use. These questions become more violent when we try to understand the interaction between human development and the environment.

\subsection{Development and the environment}


The history of economic development has hardly been formed without its impact on the environment. Technically, development refers to the process of change or transformation. The development indicates improvement, progress, and development. Hence, economic development means the development of economic affairs or activities. According to economic development researchers, improved tools and techniques are necessary to develop or promote economic activities [4]. The history of human economic activity has traversed the agricultural age, the industrial age, and the information age. Prehistoric agriculture included hunting and feeding with simple tools such as a shovel and a stick. Agriculture became a scientific trade through the scientific revolution and the industrial revolution of the 17th century and emerged as an industry. The advent of industrial agriculture marked a turning point in economic development. Hence, large-scale agriculture has led to the use of artificial fertilizers and pesticides, the formation of large-scale livestock farms, antibiotics and hormones, and dependence on machinery have become current issues [5].

The continuation of the industrial revolution, which brought about industrial development, especially industrial agriculture, has had a detrimental effect on the environment in various ways. Economic development has also had negative and detrimental environmental consequences [6]. The gift of industrialization has been the uncontrolled consumption of water resources. That is, groundwater and watersheds are consumed faster than they can be regenerated. Irregular energy consumption is also characterized by economics. For example, with special reference to agricultural development, it should be said that heavy agricultural machinery needs a lot of energy, and a lot of energy is spent on the production of nitrogen fertilizers and pesticides. In addition, the transportation of food over long distances requires a lot of energy. These are all air pollution topics due to the consumption of large amounts of fossil fuels, which in turn causes global warming.

Due to the development of biotechnology, farmers have resorted to the use of chemical fertilizers to increase production. The effect is a significant reduction in soil ability to retain moisture and a strong dependence on irrigation systems. Moreover, groundwater and surface water are contaminated by the use of herbicides and insecticides [7]. The result of these anthropogenic activities of agriculture and large-scale industrialization is a constant threat to human life and other living things. This question is appropriate here; Is it fair for human beings to treat the environment in any way they want in the name of development? And it is precisely this question that has created the need for this study to examine the issue of environmental justice in the face of sustainable development concerns with particular reference to developing economies.

\subsection{Human needs and environmental justice}

Man needs food, clean water, education, income, and good health. Poverty is the cause of the inability to meet these basic needs. So poverty is a threat to the sustainability of human life. Human rights are derived from these basic human needs. In other words, human beings have the right to food, water, education, health, and so on. The absence of any of them can cause negative chain reactions. For example, lack of food weakens the human immune system, and the weakened immune system causes malnutrition; malnutrition opens the door to diseases and illnesses [8].

Human needs for food, housing, clothing exist in any socio-political and economic system. Therefore, the right to the necessities of life, which is an indicator of human rights, is universal and inalienable. Therefore, talking about the right to the environment, equality or environmental equality, and environmental justice is logical, and the phenomenon of environmental justice means fair behavior and meaningful participation of all human 
beings regardless of race, color, gender, nationality, or income concerning the development and implementation of laws. , Environmental regulations and law [9]. Therefore, the right to the environment is an undeniable necessity.

According to researchers, environmental justice is associated with a social change towards meeting basic human needs and improving the quality of human life, in other words, the quality of education, health care, housing, human rights, environmental protection, and democracy [10]. By analyzing the various definitions and concepts of environmental justice, David Schlossberg [5] introduces the four main issues in the category of environmental justice as follows:

- Equitable distribution of environmental risks and benefits;

- Fair and meaningful participation in the environmental decision-making process;

- Recognition of social lifestyle, local knowledge, and cultural differences;

- The ability of communities and individuals to do work and flourish in society.

Therefore, environmental justice in the search for fair behavior is related at two levels: fair human behavior and fair environmental behavior [11].

People need a rehabilitative environment to realize their right to the necessities of life. For example, the fair thing that $X$ should do is to create an enabling environment for others to enjoy their rights, and others should compensate him. X's environment includes living, working, playing and learning, and so on. On the contrary, what is fair about the environment is that everyone, including $X$, protects the environment and keeps it safe and sound.

Bojan Bryant has expressed his concern about a proper understanding of environmental justice, that when people reach their full potential, they have served environmental justice, especially since environmental justice is the right relationship between humans and the planet [12]. Environmental justice focuses on humans and other vulnerable creatures at risk of destructive and greedy human activities. Environmental justice, which is necessarily human-centered from the point of view of ethics, seeks to promote human well-being and social equality while at the same time not underestimating endangered species and environmental health [13].

Proponents of environmental justice have sought to compensate for the unequal distribution of environmental burden through a proposal to guarantee equal rights to the environment. However, environmental burdens that can prevent people from realizing their potential include pollution, industries, industrial facilities, and crimes [14]. Hence, what is considered environmental injustice has several causes.

The main cause of environmental injustice is illegal changes in land, water, energy, and air. For example, when the abusers of land, water, energy, and air are not dealt with without discrimination, wildlife and human life will suffer the consequences. In this regard, the vast deforestation in the name of human development has caused incalculable damage to the world's natural resources [15]. Industrial advances have always threatened the environmental rights of early inhabitants around the world. Aquatic life has not been spared from dealing with water users without discrimination. Coastal communities around the world depend on water for livelihoods, transportation, and so on. In particular, fishing is a real source of income for beach communities. So, if humans do not treat water with respect, the livelihood of some people will be jeopardized.

Energy change and climate change are similar to the causes of environmental injustice. For example, burning gasoline and exploring fossil fuels have contributed significantly to the degeneration of the environment in many parts of the world. Areas such as the Persian Gulf or the Caspian region, and the Niger Delta in Nigeria are rich in crude oil. Today, however, indigenous peoples in most crude oil exploration areas appear to be facing environmental injustice. Simultaneous land, water, energy, and air has brought about environmental degradation and associated injustice [16]. 
Among other reasons, the failure of governments to formulate responsible and accountable government policies and regulations has been recognized as a cause of environmental injustice. The lack of recognition of the rights of others to a clean, safe and healthy environment has also been attributed to governments failing to address the need for thoughtful government policies and regulations on environmental pollution, especially in developing countries. The mindset of developing countries where environmental injustice is ostensibly common is that governments should wait for environmental pollution to occur and then look for a solution.

Institutionalized racism also threatens environmental justice. The tendency to consider the environment or region of some people inferior to others also causes injustice. The truth is that the poor of the world are mostly found in black communities. The intellectual tendency, then, is that local black communities are polluted and polluted by the environment. This explains why black communities around the world are an accessible place to dispose of waste. And because poor communities (or races) lack the interests and power to fight advanced industrial communities or races, they succumb to fate.

Environmental racism, which seeks to polarize the world and create new communities, a lower environmental community, and a superior environmental community, causes environmental injustice. From what has been said, it follows that not everyone enjoys equal protection against environmental and health hazards, and at another level of injustice, not everyone has equal access to the decision-making process for a healthy environment [17].

The same is evident at the level of international relations. The relationship between developed and developing countries regarding the global environment's treatment indicates environmental inequality and injustice. Advanced or industrialized economies are the worst polluters. Advanced economies do not respect the environment of developing countries because toxic industrial wastes often make their way to landfills in developing countries.

\subsection{Sustainable development and environmental injustice}

Sustainable development and environmental justice phenomena come into play during the search for growth and development in developing economies. Sustainable development means meeting the present generation's economic, environmental and socio-political needs without endangering future generations [18].

Sustainable development is a single phenomenon with three dimensions: from one socio-political dimension, the second economic dimension (economic sustainability), and the third environmental dimension (environmental sustainability). But these three dimensions of sustainable development are intertwined in the form of an intertwined coil. So, it becomes almost difficult to place these areas of sustainable development in impermeable enclosures. Thus, for example, socio-political activities (such as war) affect economic activity (e.g., wartime budgets) as well as the environment (heavy use of weapons that destroy the environment).

Sustainable development comes to mind in the sense that resource consumption should be such that it does not run out in the short term. So, for example, the question we ask about the West Asian region is what contribution has West Asia, and the Middle East made to global efforts towards the sustainable use of natural resources? And if the goal of sustainable development is to meet the needs of the people while maintaining the comprehensiveness of the environment; Do most Middle Eastern countries pass the Sustainable Development Exam? The answers to these questions include themes for sustainable development and environmental justice in the region [19]. 
Undoubtedly, the region of West Asia enjoys the blessings of natural resources: for example, vast arable lands, rivers and minerals, and so on. Africa is one of the most prosperous regions on the continent, but it is also home to extreme poverty, unimaginable misery, and unprecedented environmental degradation [20]. Environmental justice is a huge vacuum in rich regions like Africa, and it can be said that the African environment does not support environmental justice. The environmental rights of the average African - for example, the right to food, clean water, and a healthy environment - are often threatened by a lack of environmental education based on environmental issues.

Sustainable development, which guarantees these rights, is based on a clear understanding of the place of the environment in the human yard. Humans are each born in a place (in the environment); They grow up in an environment, and their beliefs and values are influenced by their relationship with those around them (the environment). Human beings' failure to respect the environment leads to food crises, floods, and threats to humans and wildlife. For example, countless birds, animals, and plants are on the endangered species list in wildlife. All over the world, most of the wildlife and the most beautiful natural resources on the planet have been abandoned in the name of development. And many animals are dying because of the loss of their natural habitat. The extinction of wildlife contributes to the poverty of human existence. The chain of ecosystems that preserve human life is broken every time a species becomes extinct.

Today, this view of environmental justice is considered a problem and a limitation, which is the best approach to this important internationalization of environmental protection and respect [21]. In any case, to achieve environmental justice, a fundamental change in worldview, we need and must have the positive impact of change to challenge human communities to understand a more comprehensive view of things [22]. Environmental justice is embedded in a vision for broader justice, and efforts to promote economic justice and political power do not marginalize environmental justice [23, 24].

\section{Conclusion}

Regulations generally include rules that specify permitted and prohibited activities concerning individuals, companies, or government administrative bodies and are accompanied by penalties or rewards, or both. Social regulation also aims to limit or prohibit behaviors that directly threaten public health, safety, and public welfare. These threats include environmental pollution, unsafe work environments, unsanitary living conditions, and social deprivations, and social regulation addresses the behavior of individuals, companies, and lower levels of government. In this regard, the new approach of regulatory organizations is to facilitate regulations and promote community acceptance and compliance with regulations.

Governance decisions have the same effect as a regulation. Although some believe that all decision-making is sovereign and citizens have no role, this is a wrong view because wherever the general public disobeys the law, it is a sign of a violation of sovereignty in decision-making. Therefore, public diplomacy is still ongoing, and this is also reflected in environmental decision-making. This process takes place in a standard context and follows environmental regulation. Now, this environmental regulation includes various dimensions. This trend shows the coherent efforts of civil society on the circuit of environmental decision-making.

In this regard, it is suggested that environmental regulation, which certainly reduces the gap between commitment and compliance with environmental law, should be prioritized by competent organizations, which is important when its effects are realized. And a clear example of this is institutional arrangements for environmental decisions at the na- 
tional level. Thus, environmental regulation operates in all national and international sectors and thus reflects the transnational nature of the environment and the vastness and diversity of individuals and organizations, including countries affected by environmental decision-making in the light of public and environmental diplomacy.

In recent decades, the gradual development of international environmental law has been based more on human-environmental needs and necessities than anything else. Economic growth and increasing technological advances in the contemporary period have caused fundamental damage to the environment. In response to these needs and requirements, international law has sought to bind governments to environmental protection by enacting international laws and regulations. Although the international community has made great efforts to enforce binding and non-binding legal instruments for global environmental protection, these efforts have failed to stop the widespread environmental degradation in the world. In terms of the content of the law, creating a comprehensive system of international environmental law can reduce the legal gaps created by the multiplicity of environmental legal documents. In addition, one of the ways to reduce the existing challenges is to adopt an approach of "internationalization" of environmental protection, which is based on two legal bases.

On the one hand, the basic rules and regulations of international environmental law bind on members of the international community. The legal basis of these rules and regulations is mainly "customary" and is based on customary law, some of which are now known as "international rules." On the other hand, some of the basic principles of international environmental law, such as the principle of "prohibition of harm to other lands," the principle of "fair and rational use of land," the principle of "cooperation," and the principle of "prevention" should be considered in global environmental protection. Therefore, international law's conceptual and substantive development can be considered an effective solution to the limitations and obstacles to international environmental law.

On the other hand, "internationalization" of environmental protection on the principle of "institutionalization" of international law is based on the contemporary environment. Institutionalization of international law means creating and expanding international organizations and institutions for the effective and efficient protection of the environment. Also, participation in the domestic dimension includes public participation in environmental decision-making and implementation of environmental decisions and participation in the international dimension overseeing the participation of all governments, both rich and poor, developed and developing, industrial and non-industrial in decisionmaking. Therefore, internationalization can be one of the important strategies for the development of international environmental law.

Also, the criminalization of large-scale environmental degradation and the passage of "crime against humanity" through the recognition of "crime against future generations" can be a sign of progress in the sense of extra responsibility for the future, future conditions, and protection of other living species and the environment is considered. International criminal law does not yet have clear legal solutions to criminalize environmental degradation as international crimes; however, recognizing "crime against future generations" as an international crime could extend to international environmental law.

Structurally, the transformation of the United Nations Environment Program, which currently has limited capacity, into a "global environmental protection organization" with the necessary authority and power, could be an important step in the structural development of international law. Consider the environment. The issues related to establishing this global organization will not be outside the conflict of developing and developed countries. 


\section{References}

[1] Hadi Far, Davood, 2010, Legal Regulatory Enactments: Structure and Mechanism of Action, Tehran, Oct. 13, p. 32.

[2] Joskow, Paul L. and Roger G. Noll. 1981. "Regulation in Theory and Practice: an overview, "in Studies in Public Regulation. Gary Fromm, ed. Cambridge, MA: MIT Press.

[3] Jacint Jordans \& David Levi-Faur,2007, The politics of regulation in the Age of Governance, in Jacint Jordans \& David Levi-Faur (eds.), The Politics of Regulation, Edward Elgar, 2004, p. 8., Tony Prosser, Regulation, Markets and Legitimacy, in Jeffrey Jowell \& Dawn Oliver (eds.), The Changing Constitution, Oxford University Press, Sixth Edition, p. 339.

[4] A Ogus,1994, Regulation: Legal Form and Economic Theory, Oxford, Clarendon Press, p33.

[5] Shams, Erfan, 2011, Economic Regulation, Principles, History and Methods, Research Center of the Islamic Consultative Assembly, No. 12, p. 1. (In Persian)

[6] Shams, Erfan,2011, Structure, Competency, and Accountability of Regulatory Institutions (Iran-UK), Shahid Beheshti University, p. 10. (In Persian)

[7] Hadavand, Mahdi ,2008, An Introduction to Economic Regulation, Majles and Research, Fourteenth, No. 56, p. 55. (In Persian)

[8] Kasemets, Aare,2001, Impact Assesment of Legislation for Parliament and Civil Society: A Comparitive study, p 49.

[9] Holmes, Sue,2001, The Best Practice on Regulatory Impact Assesment in OECD Countries: Some Options For RIA, ECPRD Seminar, $\mathrm{p} 36$.

[10] Monville, Quenchy,2011, The Effective Improvement of Parliamentary Procedural Procedures, Hassan Vakilian (Compilation and Translation), Speeches in Law and Legislation, Research Center of the Islamic Consultative Assembly, p. 280. (In Persian)

[11] Tayebi, Sobhan,2016 Environmental Diplomacy in the Light of International Interactions and Global Peace, Ph.D., Environmental Law Department, Tehran University of Science and Research, p. 234. (In Persian)

[12] Martin Minogue, Governance-Based Analysis of Regulation,2001, Centre on Regulation and Competition, Working Paper Series, Paper No. 3, pp. 2-3.

[13] Fiorino, J.D. 2006. The New Environmental Regulation, The MIT Press, p189.

[14] Brand U, Görg C, Hirsch J, Wissen M,2008. Conflicts in Environmental Regulation and the Internationalisation of the State, Routledge, p16.

[15] Malmiri Markaz, Ahmad,2010, The Impact of the Quantity and Regulatory Quality on the Business Environment, Research Center of the Islamic Consultative Assembly, No. 12313, March, p. 17. (In Persian)

[16] Faryadi, Masoud, 2010, Legal mechanisms for assessing the effects of regulation in Iran's legal system, p. 11. (In Persian)

[17] Bronwen B, Yeung K,2007. An Introduction to Law and Regulation Text and Materials, Cambridge University Press, p36.

[18] Anto Donald K., (2012), "The 2012 United Nations Conference on Sustainable Development and the Future of International Environmental Protection", Consilience: The Journal of Sustainable Development, Vol. 7, Iss.1

[19] Poorhashemi SA, Arghand B, International environmental law, Nashr Dadgostar, 2013 (In Persian)

[20] Poorhashemi S. A., B. Khoshmaneshzadeh, M. Soltanieh \& D. Hermidasbavand, (2012), "Analyzing the Individual and Social Rights Condition of Climate Refugees from the International Environmental Law Perspective", International Journal of Environmental Science and Technology, Volume 9, Issue 1.

[21] Hosseini, Mehdi (1392), International Governance and Sustainable Development Challenges in Developed Countries, Journal of Environmental Science, No. 56. (In Persian)

[22] Poorhashemi, S. A., \& Motlagh, A. P. (2017). Legal instruments dealing for scientific uncertainty in precautionary principle from the perspective of International Environment Law. The Statute of the International Court of Justice (ICJ) (1945) http://www.icjcij.org/documents/?p1=4\&p2=2

[23] Kiss. A. et J.P. Beurier, (2004), Droit international de l'environnement, Paris, Pedone, 2004.

[24] Harvard Law Journal (2001), International Environmental Law, Mousavi, Seyed Fazlollah (Translator), First Edition, Tehran: Mizan publisher. (In Persian) 